"Mircea cel Batran" Naval Academy Scientific Bulletin, Volume XIX - 2016 - Issue 1

Published by "Mircea cel Batran" Naval Academy Press, Constanta, Romania // The journal is indexed in:

PROQUEST / DOAJ / DRJI / JOURNAL INDEX / I2OR / SCIENCE LIBRARY INDEX / Google Scholar / Crossref /

Academic Keys / ROAD Open Access / OAJI / Academic Resources / Scientific Indexing Services / SCIPIO

\title{
OPTIMIZATION OF SELECTION CRITERIA AND OF THE MEANS OF GUIDANCE OF SWIMMING ATHLETS
}

\author{
Elena HANU ${ }^{1}$ \\ Silvia TEODORESCU² \\ Carmen ENE-VOICULESCU ${ }^{3}$ \\ ${ }^{1}$ Prof.Dr. National College Mihai Eminescu Constanta \\ ${ }^{2}$ Professor PhD, UNEFS Bucharest \\ ${ }^{3}$ Professor PhD, Ovidius University, Faculty of Physical Education and Sport, Constanta
}

\begin{abstract}
This paper aims to summarize some aspects that define the specificity of sports activity in the swimming discipline in terms of the rules and criteria governing the sports selection for performance swimming. The perfection of training the athlete is highly influenced by technicians who must assume with responsibility this "holy" mission of modeling and development of the athlete in the context of high performance sport industrialization. Selection in sport is a complex, directed, which aims to highlight those young kids with high potential, and under the influence of methodological and scientific training, lead to great performance. This complex system meets all the criteria, selection rules in the concept of " selection model " / "constitutional biotype" characterized by certain physical, motor and behavior qualities specific to each branch of sport. As a key factor in obtaining sports performance, the selection process has a continuous character and depends on the interface of several factors: social, economic, cultural, biological, methodical, technical.
\end{abstract}

Keywords: selection, sports, performance, criteria.

Sport as a vector of values such as solidarity, team spirit, tolerance and fair play contributes to the development of knowledge, to the personal fulfillment of each individual.

Sports in all its forms of physical activity, reunited by means of a participation organized or not, is a phenomenon of modern social life through its uniqueness and universality and is aimed at improving the human being.

\section{INTRODUCTION}

In addition to its biological dimension physical activity acquires a social dimension, movement (human motility) becoming a socialized and socializing activity, but also cultural and cultured alike. Physical activity is a carrier of meanings, both for the one who actually performs it, and for the one who observes it, who assists and guides it.

The athlete is that person engaged physically and morally for self-improvement in individual and collective social deeds and actions, who creates important values for the society. He becomes a special model with a special human construction and adaptable to morpho-psycho-functional and ample social dimensions and can support a multidisciplinary modeling through concurrent and alternative, immediate and cumulative processes. The athlete performs a complex motor activity with internal organization which bears the stamp of the features of each one, representing that motor coding, as a defining element of one's own personality.

\section{ESSAY CONTENT}

In the last two decades, professional sports reached a multitude of biological, socio-economic, psycho- pedagogical, technological valences, thus making insufficient the natural selection alone and boosting sport science directed towards applying a guided selection. The mechanisms and selection criteria in sports have profound implications in the field of genetics and anthropology, physiology, biomechanics and psychology, sports medicine, cybernetics and informatics, pedagogy, methodology of training, and social economy.

In order to choose the most talented and gifted children who following a rigorous training process and applied scientifically can achieve maximum athletic performance, we need a repeated and organized process for early detection of inborn availability for practicing and subsequent specialization in a sports discipline or field. The degree of success in sports talent identification process depends on the ability to quantify and overlap the qualities of sports athlete over the requirements of the sports discipline concerned. The selection, in general, is a complex multidisciplinary and integrated process system comprising on the one hand medical history, that 


\begin{abstract}
"Mircea cel Batran" Naval Academy Scientific Bulletin, Volume XIX - 2016 - Issue 1
Published by "Mircea cel Batran" Naval Academy Press, Constanta, Romania // The journal is indexed in: PROQUEST / DOAJ / DRJI / JOURNAL INDEX / I2OR / SCIENCE LIBRARY INDEX / Google Scholar / Crossref /

Academic Keys / ROAD Open Access / OAJI / Academic Resources / Scientific Indexing Services / SCIPIO
\end{abstract}

of personal history and, on the other hand family medical history that gives us information on: morphological configuration of the child and parents, the cultural, educational level, sports attitude of parents, child, family sports history, psychomotor behavior, intelligence.

The influence of social context on sports performance is an important concern of experts in the field that raise the question of identifying "talents" for sport, with an optimal morphological and functional profile, with an extraordinary psychomotor ability, with a motivation for sport. Merging and harmonious combination of the elements of the motor activity, structured on skills, abilities and capabilities, leads to the completion of the sports architectural sports talent, performance, motor excellence.

The concept of selection in sports can be a permanent innovation under the terms of formulas, indices and criteria used by passing from the conditioning factors of sports development to the complexity of all parameters of efforts with beneficial effects for the athelete.

Considering the selection as a dual-purpose method, that of diagnosis and of prognosis, we can define the structure elements of the sports selection model.

The selection process is a socio-sports process, rational, dynamic and complex developed in a social reality in which the object of selection is the athlete subject to selection and phase-sorting and the suject is the specialized framework constantly concerned to modify the object to heights higher and higher on the sporting and social route. In essence, the selection is a process is a permanent selection of athletes, in order to guide and orient them to a sports field or branch in which he/she manifests motivations and skills.

In this paper we express the intention to develop several particular issues, related to the selection of sports for swimming, issues less addressed in the research literature of the field. One of the problems faced by Romanian swimming in selecting future swimmers is anticipation of the physical constitution of the future adolescent, investigating the child anthropometrically and somatoscopically. The chaotic evoilution of the society, the tumultuous life and economic and social transformations, show clearly that the biological model of the performer varies substantially from one decade to another. Therefore we consider that in case of the issue of selection of future swimmers we must give proof of clairvoyance, mobility and rigorous prognosis. When it comes to swimming, as a means of transport by water, we refer to the aquatic environment denser than air by 770 times. The aquatic environment calls for an a sensor-motor adaptation "atypical and unusual to the human being".

At this time, the general trend is that the primary selection for swimming is made at a more early age. Thus, a body in a dynamic of growth and development, with "exponential" modifications at puberty - must adapt to different types of efforts.

Sports effort is a biological stimulus which by its volume, intensity and complexity, forces the body to react intensely and generalized at muscular, cardiovascular, respiratory, endocrine-metabolic, nervous level.

Considering sports performance dependent on the relationship TASK-ACTIVITY-RESULT we shall follow the identification of those elements that constitute a real hyper-complex and dynamic, multidimensional system, represented by a human construction with a special structure and adaptable to large sizes, morpho-psychofunctional and social, in order to define the "selection model" in case of swimming as a conditional step of selection in performance.

Obtaining sports performance is subject to 2 broad categories of factors presented below in a complex scheme, which is a special socio-sports equipment conditioned both by the athlete and by specialized professionals, environment, and institutional forms and their policy.

\section{EXTRINSIC FACTORS:}

\section{$>$ The political factor: \\ * Social order \\ * Development and intersectional cooperation strategies}

$\begin{array}{ll}+ & \text { School and performance sports programs } \\ + & \text { Institutional sports facilities } \\ > & \text { Social factor: } \\ + & \text { Demographic indicators } \\ + & \text { Family } \\ + & \text { School } \\ + & \text { Quality of life: } \\ 0 & \text { Social origin } \\ 0 & \text { Lifestyle } \\ 0 & \text { Integrity and social cohesion } \\ 0 & \text { Unsporting and social discrimination } \\ \text { practices } \\ +\quad \text { Sports environment } \\ >\quad \text { Economic factor: } \\ 4 \quad \text { The personal financial availability }\end{array}$


"Mircea cel Batran" Naval Academy Scientific Bulletin, Volume XIX - 2016 - Issue 1

Published by "Mircea cel Batran" Naval Academy Press, Constanta, Romania // The journal is indexed in:

PROQUEST / DOAJ / DRJI / JOURNAL INDEX / I2OR / SCIENCE LIBRARY INDEX / Google Scholar / Crossref /

Academic Keys / ROAD Open Access / OAJI / Academic Resources / Scientific Indexing Services / SCIPIO

\# Institutional financial availability

* Professionalism in sports

$>$ Cultural factor:

* Sports culture

* Culture for sports

* Sports Media

2. INTRINSIC FACTORS OF SPORTS PERFORMANCE:

$>$ Selection:

+ Hereditary component:

o Somatic

o Functional

o Biochemistry

o Psycho-intellectual

o Psycho-affective

o Volitional psycho-regulating

* Skills component:

o General skills

o specific skills:

* Motor general

* psychomotor

* Motor

$\$ \quad$ Attitudinal component

$>$ Training:

* Training phasing

* Training Planning

* The systematization of methods and means of training

* Developing motor skills

* Technical and Tactical Training

* Availability to the effort

* Psychological training

* Machinery, equipment

* Locations and types of training

* Diet and sports medication

* The interdisciplinary team

$>\quad$ Personal development:

* Sports form

\$ Efficient competitive system
Sports recovery and rehabilitation

What is essential for obtaining valuable sports results is to identify these tests of motor efficiency and of psychological tests which to build the model of selection and sports orientation and further to develop standardized training programs of sports talent.

In swimming sports branch, the selection process, whether we speak of a spontaneous, empirical or scientific selection we must take into account the performance premises, the effort capacity structure, the physiological characteristics of effort. Swimming effort falls into the group of predominantly aerobic effort (aerobic energogenesis), except 50 and 100m competitions which have an anaerobic dominant character. Considering the aquatic environment where the effort is made, there is a series of adaptive processes of the body subject to specific sports training, of which we shall mention: thermoregulation activity, cardiovascular system load due to the horizontal position of the body, buoyancy, coordination of movement specific to swimming with the respiratory act, download of spine. Due to its complexity, athlete swimmers must show a highly developed "sense of water", of will, daring, resistance to stress and monotony, a capacity to overcome the unpleasant states (suffocation, muscle exhaustion, shortness of breath) and capacity of concentration of long-term attention in case of fatigue, suffering ability, resistance to frustration, a sense of discipline.

In recent years, we have been witnessing the evolution of a phenomenon that can be dangerous for the future of professional sports. Sport practice shows that there are more and more parents who subject their children to intensive sports training, without knowing and without fully accepting their level of skills endowment, and the most negative aspect is that of total ignorance of the child's aspirations and desires. Another element that led to the increase in the percentage of children who do not remain in professional sports training is experts' attitude in the training process, aimed at rapidly obtaining the maximum sports result without resorting to the components of a scientifically rigorous selection and training system.

Professional sports activity is reserved for adolescence and youth, the age at which skills are obvious, the motivation for performance is superior, aspects that lead to an easy adaptation of the athlete to the demands of training. This concordance between skills and attitudes is the 


\begin{abstract}
"Mircea cel Batran" Naval Academy Scientific Bulletin, Volume XIX - 2016 - Issue 1
Published by "Mircea cel Batran" Naval Academy Press, Constanta, Romania /I The journal is indexed in: PROQUEST / DOAJ / DRJI / JOURNAL INDEX / I2OR / SCIENCE LIBRARY INDEX / Google Scholar / Crossref /

Academic Keys / ROAD Open Access / OAJI / Academic Resources / Scientific Indexing Services / SCIPIO
\end{abstract}

basis of success in any branch of sport and further, the process of educational training has the greatest degree of success.

From the practical activity as a teacher and coach, and the study of research literature I can highlight some aspects on the significance of selection in sports:

- Sports selection is a sum of methodological and practical consequences which operate on the child establishing its field of activity for the entire life of sports performance.

- Today the possibility of progressive selection in stages from the spontaneous phase, through the empirical phase and ending with the scientific one is not taken into account, as the percentage when a coach is "lucky" to find highly-talented athletes or when gifted athletes are lucky to meet a talented coach to reach the heights of sports success is still high.

The field of professional sports operates excessively with selection at early ages (6-8-10 years) by indicating the different examinations and tests specific to each sport branches using sanogenetic and somatic criteria, placing second the qualities regarding the features of the type of nervous system, the basic traits of character, the stability of mental processes and of the capacity of guiding them during training and competition.

- The highly specialized nature of sporting disciplines, through the technique and training features make it impossible to "rethink", to change the sports or even the completion after a number of years which have not confirmed the initial selection, which is often carried out in particular on the basis of preferential decision, although it is not under cover by skills and attitudes. This feature of professional sports shows the need to implement certain methodical provisions in order to achieve first a correct sports orientation, observing the principle "right man in the right place" aimed at general sports training and then introducing those methods directed at a particular sport. We believe that discernment, moderation but especially the care for the route of the future athlete should be a priority in front of other random and immediate sporting success.

- We express our opinion that in the very near future sport selection decision will have to give up the exclusive testing of skills and the exaggerate forecasting of future performance and create a balance in which greater weight is granted to the selection based on psycho-behavioral indicators of athletes able to objectify those sensory perception related qualities and the skills related to the structure of personality, of those of the temperamental, character field, of motivational performance capacity.

Through the data and issues presented we have tried to express some opinions and findings on the sports selection and orientation, from the point of view of the teacher and coach, perhaps of less immediate practical implication, but definitely for perspective, which will lead to a stimulation of the creative thought of all specialists involved in this integrated process: medico-biological, socioeconomic, technical and pedagogical.

\title{
BIBLIOGRAPHY
}

[1] "Selectia si Orientarea Medico-Sportiva" (Medical-Sports Selection and Orientation)- (1989)- Edit. Poligrafica Bacau, Romania

[2] CIRLA. L., - “ Inot -Aptitudinile Psihomotrice si Pregatirea Tehnica “ (Swimming- Psychomotor Skills and Technical Training) -(1999) - Printech Publishing House, Bucharest,

[3] TEODORESCU, S. (2009) - Antrenament şi competiţie (Training and Competition). Alpha MDN Publishing House, Buzău.

[4] TEODORESCU, S. (2009) - Periodizare și planificare în sportul de performanță (Periods and planning in professional sports), Alpha MDN Publishing House, Buzău. 